Copyright (C) 2021 by Cherkas Global University

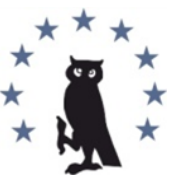

Published in the USA

Russkii Arkhiv

Has been issued since 1863 .

E-ISSN: 2413-726X

2021. 9(2): 143-164

DOI: 10.13187/ra.2021.2.143

https://ra.cherkasgu.press

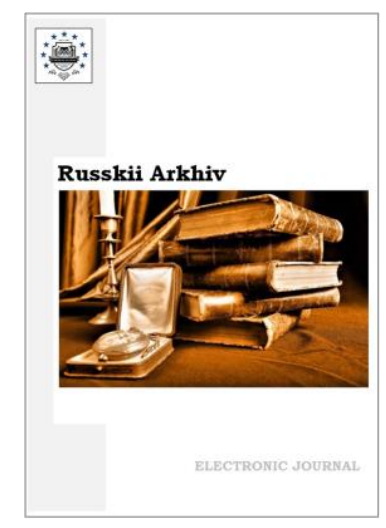

\title{
Articles
}

\section{From the History of the Russian Diaspora: The Letters from F. Alexandrov to A. Florovsky}

\author{
Valery V. Levchenko ${ }^{\text {a }}$ \\ a Odessa National Maritime University, Ukraine
}

\begin{abstract}
The article contains 13 letters from the Russian scholar and emigrant F. Alexandrov to A. Florovsky. They help illuminate many aspects of the life of Russian scholars and emigrants in Bulgaria in the 1920 s and 1960s. The correspondence reflects some aspects of the cultural and social events of the Russian diaspora. Amongst others, the discussion of issues of employment, adaptation, material improvement, etc. is of particular interest. The letters make it possible to supplement the biographical outline of the life of F. Alexandrov and A. Florovsky and gather new information for them, which were not previously mentioned in the biographical articles of the two correspondents. The many details of their pedagogical, scientific and private life can remarkably compliment the prosopographic portraits of the two scientists.

Keywords: F. Alexandrov, A. Florovsky, Russian abroad, Sofia, Bulgaria, epistolary, correspondence, historiography.

\section{Читать старые письма приятно уже потому, что на них не нужно отвечать. Джордж Гордон Байрон (Душенко, 2003, 588)}

Эпистолярий ученого дает возможность исследователю его биографии максимально допустимо детализировать воссоздание истории человека на фоне социокультурного пространства эпохи, позволяя определить психологический тип личности в исторической, политической, национальной и социальной обусловленности, приблизиться к пониманию принципов работы, творческих замыслов, коммуникативных связей, мировоззрения и т.п. Переписка сохраняет информацию просопографического характера, необходимую для реконструкции жизненного и творческого пути человека. В интеллектуальном наследии одного из крупнейших историков русской эмиграции профессора А.В. Флоровского (1884-1968) видное место принадлежит переписке (Лаптева, 2017: 277-313). Сохранившееся эпистолярное наследие ученого стало ценным историческим источником исследования его преподавательской, научной и общественной деятельности, профессиональных и семейных отношений. Особый интерес вызывает переписка А.В. Флоровского с коллегами в период эмиграции.
\end{abstract}




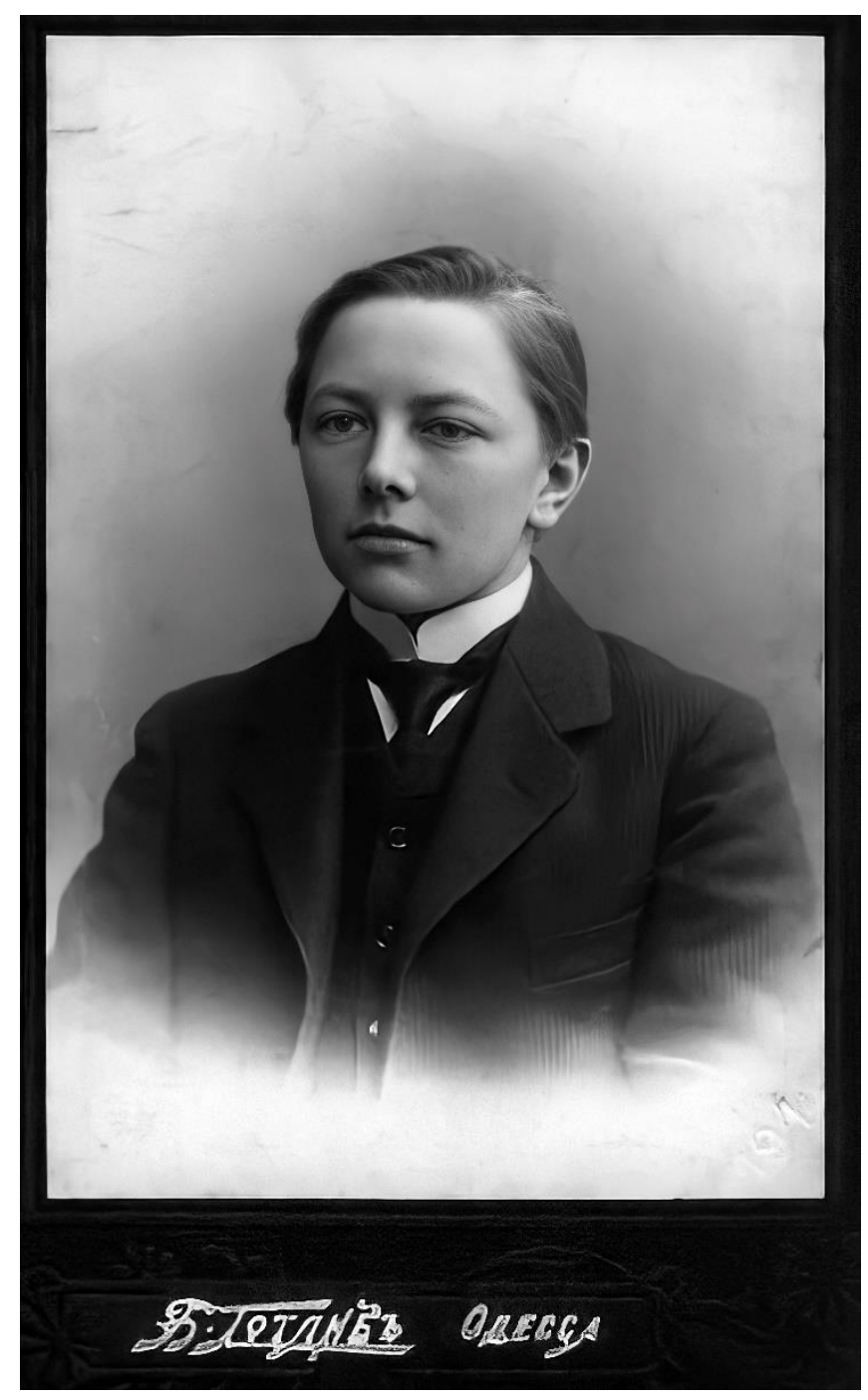

Рис. 1. Фото А.В. Флоровского. Одесса, 1910-е гг. (АРАН. Ф. 1609. Оп. 1. Д. 186. Л. 10)

Отдельные сегменты эпистолярия А.В.Флоровского рассмотрены в работах современных исследователей Е.П. Аксеновой (Аксенова, 1994; Аксенова, 1995; Аксенова, 1998), Г.А. Савиной (Савина, 2002), В.М. Хмарского (Василь Терентійович Галяс, 2006), М.В. Ковалева (Ковалев, 2011; Ковалев, 2015), М.А. Фролова (Фролов, 2019) и др. Актуальным остается вопрос освещения как можно большего количества коммуникативных связей А.В. Флоровского. Одним из его корреспондентов был коллега по работе в Императорском Новороссийском университете (ИНУ) - Федор Георгиевич Александров (1886-1981). Коллегиальные отношения Ф.Г.Александрова и А.В.Флоровского еще не становились предметом научного исследования.

Целью нашей статьи является рассмотрение профессиональных связей А.В. Флоровского и Ф.Г. Александрова в условиях пребывания в эмиграции на основании эпистолярных источников фонда личного происхождения А.В. Флоровского, хранящихся в Архиве Российской академии наук (АРАН) и документальных материалах Государственного архива Одесской области (ГАОО). 


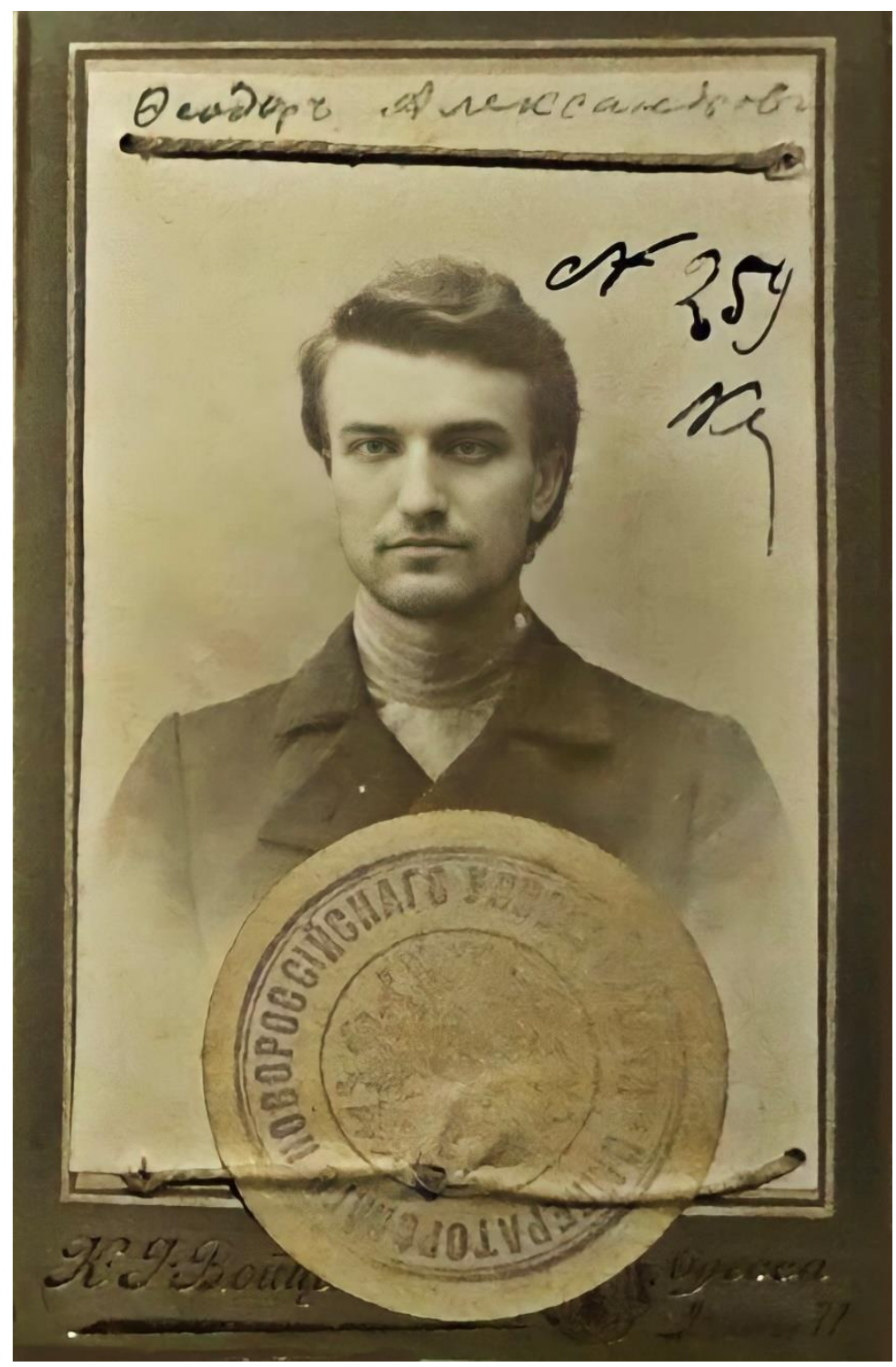

Рис. 2. Фото Ф.Г. Александрова. Одесса, 1912 г. (ГАОО. Ф. 45. Оп. 5. Д. 246. Л. 14)

В фонде А.В. Флоровского сохранено 13 автографов Ф.Г. Александрова за периоды с 10 мая 1923 г. по 29 января 1928 г. и со 2 по 28 августа 1961 г. К сожалению, в нашем распоряжении нет ответных посланий А.В. Флоровского, поэтому мы не имеем возможность реконструировать эпистолярный диалог двух ученых. Из 13 писем 7 из них ранее были репрезентованы (Савина, 2002: 339-351). Но, к сожалению, в этой публикации писем имели место неточности и упущения: в 14 случаях были допущены ошибки в прочтении отдельных слов и не прокомментированы имена многих ученых (Е.Л. Буницкого, Б.В. Варнеке, С.С. Дложевского, И.Ю. Дувана-Хаджи, В.В. Завьялова, Б.М. Ляпунова, А.С. Мулюкина, М.Г. Попруженко, Е.П. Трифильева, Г.В. Флоровского, К.В. Флоровской), с которыми многие годы была связана жизнь Ф.Г. Александрова.

Исходя из цели более полного представления картины коммуникативных отношений Ф.Г. Александрова и А.В.Флоровского в данной статье вместе с неопубликованными письмами представляем и ранее опубликованные эпистолы как один из видов письменных исторических источников. Репрезентация всех выявленных на сегодня писем (исходя из содержания переписки скорее всего других в природе не существует) Ф.Г. Александрова к А.В. Флоровскому, позволит максимально полно выявить, предельно информативно прокомментировать и встроить данные эпистолярные источники в реконструкцию конкретных исторических событий на фоне истории первой волны русского зарубежья. 
Ф.Г. Александров в отличие от своего маститого коллеги - А.В. Флоровского - является малоизвестной персоной в академическом сообществе. В научной литературе о нем имеются единичные упоминания в контексте истории высылки ученых из страны в 1922 г. (Савина, 2002; Левченко, 2008; Левченко, 2013), истории высшей школы Одессы (Левченко, 2010; Музичко, 2011), истории судеб одесских ученых в эмиграции первой волны (Косик, 2008; Левченко, 2014; Галчева, Голубович, 2015; Левченко, 2016). В связи с этим представим основные вехи его жизни и уточним бытующие в научной литературе фактологические неточности.

Ф.Г. Александров родился 5 августа 1886 г. в Елисаветграде ${ }^{1}$ в многодетной семье (всего 4 детей) не имеющего чина народного учителя православного вероисповедания Георгия Павловича Александрова, со временем причисленного к привилегированному классу городского населения - личных почетных граждан. Начальное образование Ф.Г. Александров получил дома, в августе 1897 г. поступил в Николаевское Александровское реальное училище, полный курс которого по основному отделению окончил в июне 1903 г., а в 1904 г. окончил обучение в дополнительном классе (без единой «тройки»), что давало ему возможность поступать в высшие специальные учебные заведения (ГАОО. Ф. 45. Оп. 5. Д. 246. Л. 21-27).

По окончании Николаевского реального училища и обучения на двух семестрах механического отделения Киевского политехнического института императора Александра II в сентябре 1906 г. Ф.Г. Александров поступил в число вольнослушателей словесного отделения историко-филологического факультета ИНУ. Через два года после того, как 8 июня 1908 г. выдержал экзамен по латинскому языку в объеме 8 классов гимназического курса в Аккерманской мужской гимназии 16 октября 1908 г. - был зачислен в число студентов того же отделения и факультета (ГАОО. Ф. 45. Оп. 5. Д. 246. Л. 12-13, 19-20, 32). К двадцати годам у Ф.Г. Александрова сформировалось отчетливое желание заниматься изучением языков и посвятить себя и свою жизнь этому занятию.

В годы обучения в ИНУ материальное положение Ф.Г. Александрова было очень сложным. Он был одним из студентов, кто на основании «свидетельства о бедности» канцелярии по студенческим делам ИНУ в 1911 г. был освобожден от оплаты за обучение и получал стипендию. Проживая с матерью, вдовой личного почетного гражданина, был бедного состояния и существовал на средства, добываемые частными уроками. Испытывая материальные трудности, изыскивал разные возможности для получения дополнительных средств на существование. Поэтому в ноябре 1908 г. он подал прошение на имя заведующего пенсионной кассой Юго-западных железных дорог о соискании стипендии имени графа С.Ю. Витте (ГАОО. Ф. 45. ОП. 5. Д. 246. Л. 7-10).

Несмотря на материальные трудности, Ф.Г. Александров проявлял прилежность и успехи в обучении. На III и IV курсах работал под руководством лингвистов, профессоров А.И. Томсона (слушал специальный курс «Чтение Сакунталы», изучал древнеиндийский, зендский и литовский языки) и Б.М. Ляпунова (разрабатывал тему по старославянскому языку, предложенную факультетом на соискание медали). В результате изучения этой темы Ф.Г. Александров выполнил первую научную работу под названием «О языке жития Кодрата по старославянскому списку Супрасльской рукописи», которая в 1912 г. была удостоена первой золотой медали (ГАОО. Ф. 45. Оп. 4. Д. 2007. Л. 60; Ф. 157. Оп. 1. Д. 56. Л. 1). Его медальная работа получила высокую оценку со стороны профессоров А.И. Томсона и Б.М. Ляпунова. На заседании факультета 4 декабря 1913 г. молодой ученый ходатайствуя о возвращении своей работы из Министерства народного просвещения, так аргументировал свое желание: «Профессор Б.М. Ляпунов в отзыве о моей медальной работе „О языке жития Кодрата по старославянскому списку Супрасльской рукописи“, высказал желательность напечатания части ее, т.е. словаря» (ГАОО. Ф. 45. Оп. 4. Д. 1084. Л. 41-42). А.И. Томсон в отзыве на эту работу отмечал усердие и любовь ее автора к изучению языков (Музичко, 2011: 261). Проявленные прилежание, трудолюбие и способности позволили Ф.Г. Александрову в

\footnotetext{
${ }_{1}^{1}$ А.Е. Музычко ошибочно указывает местом рождения Ф.Г. Александрова Бессарабию (Музичко,
} 2011: 261). 
1912 г. ${ }^{1}$ окончить словесное отделение историко-филологического факультета ИНУ с дипломом первой степени.

Учитывая его успехи в обучении в октябре 1912 г. факультет препроводил представление об оставлении Ф.Г. Александрова при университете для подготовки к профессорскому званию (прообраз института аспирантуры) сроком на 2 года со стипендией из сумм министерства, но департамент народного просвещения 22 января 1913 г. сообщил, что окончательное решение по этому вопросу отложено до выяснения о наличии свободных сумм на выдачу стипендий (ГАОО. Ф. 45. Оп. 4. Д. 1084. Л. 11-13, 43). Желая сохранить молодого талантливого ученого в структуре университета, 15 ноября 1912 г., согласно избранию факультета от 31 августа 1912 г. на основании представления заведующего историко-филологического кабинета ИНУ профессора Б.В. Варнеке и предложения попечителя Одесского учебного округа он был утвержден в должности хранителя этого кабинета с содержанием в 600 руб.

Для подготовки к профессорскому званию по кафедре сравнительного языковедения ИНУ сроком на два года со стипендией 600 руб. в год Ф.Г. Александров был оставлен только спустя почти полутора лет, когда предложением попечителя Одесского учебного округа от 8 марта 1914 г. было утверждено это решение, при этом считая аспирантуру с 1 января 1913 г. В последующем его пребывание в аспирантуре дважды продлевалось: 12 октября 1914 г. сроком с 1 января 1915 г. по 1 января 1916 г. и 19 ноября 1915 г. еще на один год - до 1 января 1917 г. Таким образом, Ф.Г. Александров в аспирантуре пробыл de facto 3 года, a de iure -4 года.

Проходя обучение в аспирантуре на протяжении 1913 г. под руководством профессора А.И. Томсона Ф.Г. Александров изучал монографические исследования по отдельным индоевропейским языкам, слушал специальные курсы профессоров Б.В. Варнеке («Грамматический разбор латинских надписей») и А.И. Томсона («Чтение вед», «Зендский язык»). В 1914 г. осваивал основные труды по сравнительной грамматике индоевропейских языков. В 1915-1916 гг. изучал обширную журнальную литературу, посвященную исследованиям отдельных индоевропейских языков. В марте 1917 г. приступил к магистерскому экзамену по кафедре сравнительного языковедения, который сдал удовлетворительно в мае того же года (ГАОО. Ф. 45. Оп. 4. Д. 2007. Л. 6о0б.). После прочтения двух пробных лекций на темы истории индоевропейских ударений и истории индоевропейского основообразовательного суффикса сравнительной степени он был избран в число приват-доцентов ИНУ (ГАОО. Ф. 157. Оп. 1. Д. 56. Л. 1). Таким образом, за более чем десятилетнее (1906-1917) обучение в ИНУ Ф.Г. Александров сформировался как ученый-лингвист.

Успешное обучение в аспирантуре дало основание факультету 31 мая 1917 г. избрать Ф.Г. Александрова приват-доцентом по кафедре сравнительного языковедения, что было одобрено попечителем Одесского учебного округа 8 июня 1917 г. В 1917/18 учебном году вследствие реформы высшей школы Одессы должность хранителя историкофилологического кабинета ИНУ была упразднена и постановлением физикоматематического факультета ИНУ от 29 (16) апреля 1918 г. он был избран на должность младшего ассистента указанного факультета с тем, чтобы продолжал исполнять обязанности хранителя историко-филологического кабинета без вознаграждения (ГАОО. Ф. 45. Оп. 4. Д. 1084. Л. 1-8, 14, 17-23, 27-31, 46-55, 58-61).

Педагогическую деятельность Ф.Г. Александров начал в 1915/16 учебном году в статусе внештатного преподавателя кафедры сравнительного языковедения историкофилологического факультета Одесских высших женских курсов, где прочел курс сравнительной грамматики индоевропейских языков (ГАОО. Ф. 45. Оп. 4. Д. 1084. Л. 57-58, 62; Д. 2007. Л. 6ооб.). В ИНУ начать педагогическую деятельность молодому приват-доценту было доверено на заседании факультета 26 мая 1917 г., на котором ему было поручено право чтения курса сравнительной грамматики индоевропейских языков (ГАОО. Ф. 45. Оп. 4. Д. 2007. Л. 60).

Во втором семестре 1918/19 учебного года, в период второго прихода к власти большевиков в Одессе, Ф.Г. Александров исполнял должность доцента по кафедре сравнительной грамматики и общего языковедения (ГАОО. Ф. 45. Оп. 4. Д. 2710. Л. 7, 27-28).

\footnotetext{
1 Автор данной статьи ранее ошибочно указывал 1913 г. окончанием Ф.Г. Александровым
} университета (Левченко, 2014: 155). 
После трансформации высшей школы Одессы в 1920 г. в связи с установлением советской власти, Ф.Г.Александров работал в ряде ее институтов: доцентом Гуманитарнообщественного института (1920-1921), профессором Института народного образования (1921-1922) (Левченко, 2010: 285, 341). В целом в период с 1917 по 1922 гг. преподавал курсы сравнительной грамматики индоевропейских языков, исторической грамматики греческого языка, исторической грамматики латинского языка, общее языковедение (Галчева, Голубович, 2015: 109-110).

Осенью 1922 г. судьба Ф.Г. Александрова претерпела решительный поворот. В 1922 г. молодая советская власть решилась на акцию отстранения от работы и высылку из многих городов советских республик за границу или в отдаленные районы страны десятки инакомыслящих представителей интеллектуальной элиты. Причины высылки были обусловлены несколькими факторами, главным из которых было желание власти установить жесткий идеологический контроль, путем удаления из страны научной элиты, которая могла б мыслить свободно, самостоятельно анализировать обстановку и высказывать свои идеи, а часто и критиковать существующий режим. Как следствие, осенью 1922 г. из Одессы были высланы 10 ученых, в том числе А.В. Флоровский (19 сентября 1922 г. ${ }^{1}$ в Константинополь в составе первой группы в количестве трех человек - также Б.П. Бабкин и Г.А. Секачев) и Ф.Г. Александров (в октябре 1922 г. в Варну в составе второй группы в количестве пяти человек - также Е.Л. Буницкий, П.А. Михайлов, А.С. Мулюкин, К.Е. Храневич) (Левченко, 2013: 115).

По прибытию в Варну Ф.Г. Александров перебрался в Софию, в которой легче было найти работу, где он и прожил постоянно в эмиграции. На чужбине молодому ученому пришлось жить в суровых условиях эмиграции, у него не было знакомых и родственников в Европе, и он разделил все бытовые невзгоды своих соотечественников в изгнании. Дважды ему не удавалось устроиться на историко-филологический факультет Софийского университета, где он надеялся получить хотя бы необязательные курсы. Через много лет после пребывания на чужбине он изложил свою биографию эмигрантского преподавателя всего лишь в нескольких предложениях: «С 1923 года непрерывно по 1949 год был штатным преподавателем сперва латинского и греческого языков, а потом - русского языка в различных софийских гимназиях. С 1923 же года по 1934 год совмещал с указанной работой еще и работу преподавателя русского языка и литературы в Софийской русской гимназии. В 1949 году участвовал в конкурсе на штатную должность лектора русского языка при филологическом факультете Софийского университета; в 1949 году был сперва избран гонорованным лектором, а в 1950 - штатным. Только с этого времени открылась возможность возобновить если не научную, то научно-педагогическую работу» (Галчева, Голубович, 2015: 110). Спустя 28 лет, после того как Ф.Г. Александров был уволен из высшей школы Одессы и выгнан из страны, ему удалось вернуться к работе в высшем учебном заведении, при этом в другом городе и другой стране.

Возвращаясь к письмам Ф.Г. Александрова к А.В. Флоровскому отметим, что по хронологии и проблематике содержания их условно можно поделить на три группы: 1) письма 1923-1924 гг. (№ 1-4); 2) эпистолы 1926-1928 гг. (№ 5-11); 3) послания 1961 г. (№ 12-13).

Одной из самых актуальных проблем для ученых в эмиграции оставалось решение материального вопроса и бытовых условий. В связи с этим Ф.Г. Александрову, равно как и многим другим его коллегам на чужбине, пришлось поступиться своими амбициями преподавания в вузах и браться за профессиональную деятельность в учебных заведениях низших уровней. В первые годы он работал преподавателем латинского, греческого и русского языков в средних учебных заведениях Софии, а свое положение «материальное и всякое» он характеризовал очень «тяжелыми» (№ 1). В такой ситуации Ф.Г. Александров, как человек, «лишенный всяких связей» за границей, на протяжении 1923-1924 гг. неоднократно в письмах обращался за содействием в устройстве на преподавательскую должность ко многим одесским коллегам, в том числе к ровеснику и коллеге -

${ }^{1}$ В этот день отбыл первый «философский пароход» всей общесоюзной операции, хотя во многих публикациях первым упоминается пароход, отбывший из Москвы 23 сентября 1922 г. (Левченко, 2013: 115). 
А.В. Флоровскому (№ 1-4), бытовые условия которого в отличии от других ученыхэмигрантов были немного в лучшем положении и которому удалось сравнительно быстро возобновить профессиональную карьеру. Это было связано с тем, что в Софии уже более двух с половиной лет находились его родственники (родители - В.А. Флоровский ${ }^{1}$ и К.Г. Флоровская, брат Г.В. Флоровский, сестра К.В. Флоровская и дядя по линии мамы с семьей - М.Г. Попруженко 2 ), которые еще в январе 1920 г. покинули родину и за это время преодолели трудности, возникающие перед эмигрантами в первые годы их пребывания в чужой для них стране. Не имея возможности, несмотря на покровительство авторитетных болгарских ученых - академика БАН Васила Златарского (1866-1935) и Стефана Бобчева (1853-1940), заниматься в Софии профессиональной деятельностью и перебиваясь случайными заработками, А.В. Флоровский все же был обеспечен в бытовом плане и, самое главное, имел моральную поддержку со стороны родных, что давало возможность намного легче переносить тяготы отвергнутого изгнанника.

В начале 1923 г. молодого историка-русиста А.В. Флоровского, автора чуть более двух десятков научных трудов Совет русских профессоров в Праге пригласил возглавить историко-филологическое отделение Высших русских дополнительных курсов Русской учебной коллегии, созданной в декабре 1921 г., где он вел курс русской истории. В октябре 1924 г. для чтения курса по истории русской педагогики А.В. Флоровский был приглашен на работу в открытый в августе 1923 г. в Праге Русский педагогический институт имени Я.А. Коменского. Быстрое вхождение А.В. Флоровского в научную корпорацию русского зарубежья в условиях дефицита рабочих мест и большого числа кандидатов состоялось благодаря протекции М.Г. Попруженко - признанного в российском академическом сообществе ученого. Несмотря на решение своего вопроса о продолжении профессиональной карьеры «как декан русского филологического факультета в Праге» А.В. Флоровский остался безучастным к просьбе Ф.Г. Александрова (№ 4) относительно содействия его возвращения к педагогической и научной деятельности, следствием чего стало прекращение переписки почти на три года.

В письмах второго периода - 1926-1928 гг. - Ф.Г. Александров дважды (соответственно в конце 1926 и 1927 гг.), не поднимая вопроса о содействии его возвращения к деятельности вузовского преподавателя, обращался к А.В. Флоровскому с просьбой способствовать подачи документов для продления заграничного паспорта своей мамы (№ 5-11). Если в первом случае вопрос был решен положительно, то повторная ситуация с этой процедурой на сегодня оставляет больше вопросов, чем ответов. Недосказанность в письмах 1926-1928 гг. привела к разрыву переписки на более чем тридцать три с половиной года.

Третьей темой эпистолий Ф.Г. Александрова к А.В. Флоровскому в 1961 г. была тема его лингвистических изысканий, которая частично имела положительный результат для адресанта. Исходя из содержания текстов эпистол каждого из трех периодов переписки Ф.Г. Александрова и А.В. Флоровского можем констатировать, что все три раза она была инициирована первым из них и каждый раз обрывалась на значительный период времени.

Вследствие безуспешных попыток вернуться к работе в высшей школе Ф.Г. Александров, как и многие другие ученые в эмиграции, на долгие почти сорок лет прекратил заниматься наукой, что было для него большим потрясением. По этому поводу он писал 8 июля 1923 г.: «Плохим питанием, плохим помещением (думаю, что хуже общежития трудно себе что-либо представить) меня нельзя испугать (в Чехии), но перспективой полной невозможности жить умственной жизнью - можно» (№ 2). В эмиграции научная деятельность для ученых становилась не только способом выживания, но и выполнением ценной исторической миссии - сохранить для последующих поколений дореволюционную русскую культуру, с которой они себя идентифицировали. Смысл пребывания в зарубежье

\footnotetext{
1 Флоровский Василий Антонович (1852-1928) - протоиерей, настоятель Одесского СпасоПреображенского кафедрального собора (1905-1920), в Софии настоятель русской церкви святителя Николая.

2 Попруженко Михаил Георгиевич (1866-1944) - доктор славянской филологии, славист, болгарист. Выпускник (1888), приват-доцент (1891), профессор (1908) кафедры славянской филологии ИНУ. С 1920 г. в эмиграции. Профессор истории русской литературы Софийского университета, членкорреспондент (1923), действительный член Болгарской АН (1941).
} 
представителям академического сообщества виделся в том, чтобы использовать его во благо Отечества и тем оправдать свой разрыв с народом. Несмотря на существующие бытовые и моральные трудности в повседневной жизни в процессе профессиональной адаптации ученых-эмигрантов выстраивалась ориентация на возрождение былой славы русской культуры, что позволяло находить в себе силы сохранять дух для занятий наукой.

В целом, эпистолярное наследие лингвиста и филолога Ф.Г. Александрова, сохраненное А.В.Флоровским, является примером чрезвычайно тщательного и скрупулезного учета, составления и атрибутирования документов. Опубликованные письма представляют большой интерес для историков русской зарубежной культуры. Они помогают осветить многие стороны жизни русских ученых-эмигрантов в 1920-е и в 1960-е гг. В переписке отражены некоторые аспекты культурных и общественных событий русского зарубежья. Среди прочих вопросов особый интерес представляет обсуждение трудоустройства, адаптации, материального благоустройства и др. Письма также позволяют дополнить биографические канвы жизни Ф.Г. Александрова и А.В.Флоровского и почерпнуть новые сведения для них, которые ранее не упоминались в биографических статьях двух корреспондентов. Множество подробностей их педагогической, научной и частной жизни могут послужить прекрасным дополнением к просопографическим портретам двух ученых.

Подытоживая изложенное, можно утверждать, что профессиональные связи Ф.Г. Александрова и А.В. Флоровского в эмиграции были ограниченными. Во времена, когда значительный культурный потенциал русских ученых был ограничен условиями эмиграции, Ф.Г. Александрову, благодаря присущему с юных лет трудолюбию, усердию и навыку в сложных условиях рассчитывать только на собственные силы, удалось достичь немалых успехов на поприще развития гуманитарной науки, продемонстрировать настоящую культуру профессионального отношения к делу. Эпистолии такой личности как Ф.Г.Александров являются важным источником истории развития русской гуманитарной науки.

Представленные эпистолы расположены в хронологическом порядке. Авторская дата приводится по оригиналам. Письма печатаются в соответствии с современными правилами русского языка. Подчеркивания в тексте, сделанные самим адресантом, не оговариваются. Сокращения раскрыты и отмечены квадратными скобками. Комментарии к письмам отмечены в тексте арабскими цифрами, помещены в конце писем и содержат биографические и другие объяснения. Сведения о месте хранения оригинала представлены условными сокращениями.

\section{№1}

\section{Письмо Ф.Г. Александрова А.В. Флоровскому. Варна-Прага.} 10. V. 1923 [года] Начало мая 1923 г.

Многоуважаемый Антон Васильевич,

судьбе было угодно, чтобы и я очутился в злополучной Варне. Положение материальное и всякое иное очень тяжелы ${ }^{2}$.

Вы, разумеется, догадываетесь в чем будет заключатся содержание моего письма. Я знаю, что высланные, как и вообще русские, всем надоели, в том числе и друг другу; я знаю, что получить место в каком-либо чехословацком университете невозможно, что русский университет в Праге, если таковой существует, вероятно, заполнен и притом людьми «высокой квалификации». Но все-жез, дорогой Антон Васильевич, осведомьте меня, каково положение нашей кафедры (сравнительного языковедения и санскрита; общего языковедения) в чехословацких университетах (говорят о существовании, кроме Праги, университетов в Преславле4, в Брюнне, о появлении «украинского» университета и т[ак] д[алее]); сообщите мне, пожалуйста, действительно ли положение совершенно безнадежное,

\footnotetext{
1 Указана дата получения письма А.В. Флоровским.

2 В публикации Г.А. Савиной ошибочно указано слово «...тяжелое» (Савина, 2002: 339).

3 В публикации Г.А. Савиной ошибочно указано слово «...все-таки...» (Савина, 2002: 339).

4 В публикации Г.А. Савиной ошибочно указано слово «...Бреславле...» (Савина, 2002: 339).
} 
или на что-либо можно рассчитывать. Должен сказать, что я удовлетворился бы даже какой угодно службой, если бы эта служба была в университетском городе: это давало бы мне возможность продолжать работы, пользуясь университетской библиотекой. Напишите также мне, каково положение выехавших в Германию, говорят то о какой-то Академии, то о русском университете и т[ак] д[алее]. Вообще, если Вы можете оказать мне помощь Вашим советом, - я буду Вам очень благодарен.

Если нужно будет куда-либо подавать прошение, - напишите мне немедленно об этом.

Простите, пожалуйста, что я ${ }^{1}$ позволяю себе беспокоить Вас своей просьбой, но положение человека, лишенного всяких связей, заставило меня это сделать. Я сознаю, что личное присутствие есть лучшая гарантия успеха ходатайства, однако я боялся ринутся в Прагу, не имея никаких сведений о положении интересующих меня вопросов.

Если Вы найдете, что мое присутствие и мои «хождения по мукам» смогут привести к положительному результату (minimum: какая-угодно работа, но в университетском городе), то сообщите мне об этом и я немедленно выеду в Прагу. Пишу это потому, что был частым свидетелем полной безрезультативности письменных ходатайств.

Сижу сейчас в отвратительной гостинице, из которой не чаю как выбраться. Так как сидение мое в гостинице временное, то благоволите ответ направить по адресу: Болгария, Варна, Кафе «Лилия», У. Кальфе для Ф[едора] Г[еоргиевича] А[лександрова] или лучше так: Варна, Любенова, № 10 Евг[ению] Герхардту.

Если по каким-либо причинам Вы напишите мне ответ только по прошествии двухтрех недель со дня получения моего письма, то прошу ответить по адресу: Сербия, Белград, Банк Белградска задруга (Београдска задруга), Павлу Александрову² для меня.

С искренним уважением к Вам, Ваш Ф. Александров

P.S. Только что узнал из Вашего письма к Буницкомуз куда нужно направлять ходатайства, а потому, не меняя письма, прилагаю заявление (благоволите приписать заголовок) и curriculum vitae. Никого не знаю кто бы мог поддержать мое ходатайство, а потому посылаю все это почти без надежды на успех.

Ваш Ф. Александров

Будьте великодушны уведомить меня о получении Вами этого письма с приложениями и покорнейше прошу Вас направить заявление и curriculum vitae куда полагается. Если не ошибаюсь - надо посылать в Комитет по обеспечению образования русских студентов 4 . Простите за пачкотню в письме и за «смешанное» правописание. Прочтите заявление и curriculum vitae перед подачей, дабы не было ошибок «грамматических».

Ф.A.

АРАН. Ф. 1609. Оп. 2. Д. 114. Л.1-20б. Автограф.

\section{№2}

\section{Письмо Ф.Г. Александрова А.В. Флоровскому. София-Прага. 8 июля 1923 г.}

\section{София, 8/VII 1923 [года]}

Дорогой Антоний Васильевич,

с большим запозданием получил Ваше содержательное письмо. Запоздание произошло вот почему. 19/V я выехал из Варны, направляясь в «иные страны». Приехав в Софию, я решил навестить наших дорогих одесситов. Из разговоров с Михаилом

\footnotetext{
${ }^{1}$ В публикации Г.А. Савиной это слово пропущено (Савина, 2002: 339).

${ }^{2}$ В публикации Г.А. Савиной ошибочно указано слово «...Александровичу...» (Савина, 2002: 340).

3 Буницкий Евгений Леонидович (1874-1952) - выпускник физико-математического факультета (1896), приват-доцент (1904), профессор (1915) ИНУ. В 1918-1922 гг. профессор ряда вузов Одессы. С 1922 г. в эмиграции. Профессор Карлова университета (1931-1952).

4 Комитет по обеспечению образования русских студентов в Чехословакии был образован 12 августа 1921 г. во главе с профессором А.С. Ломшаковым.
} 
Георгиевичем ${ }^{1}$, Сергеем Григорьевичем² ${ }^{2}$ Александром Дмитриевичем (Агура) 3 выяснилось, что уроки в русской гимназии Сергея Григ[орьевича], вследствие его отъезда в Брно, могут быть предоставлены мне. Оформление этого дела заняло свыше недели. Окончательно решив временно обосноваться здесь, я дал знать об этом Герхардту, который мне и прислал все письма на мое имя, скопившиеся у него.

Меня нельзя ни поздравлять, ни не поздравлять, ибо я должен был выехать. Со мной выехала семья Е. Буницкого и Дуван 4 с семьей. Как и было с самого начала, реабилитировали себя только Трифильев 5 и Ваш «однофамилец» 6 , остальные все разъехались. Что касается «незатронутых», то Оксман ${ }^{7}$ и Бузук ${ }^{8}$ пользуются большим доверием, Дложевский 9 продолжает ловко удерживаться между управляемыми и управляющими, Ляпунов ${ }^{10}$ и Лазурский ${ }^{11}$ "доживают». Университетской библиотекой заведует С. Рубинштей ${ }^{12}$. Сборник в честь Б. Ляпунова ${ }^{13}$ вышел, но, в виду спешности отъезда, я не смог его захватить. Ничего нового в области исторической науки у нас я не встречал. Картина моих дел и всех соприкасающихся обстоятельств, нарисованная Вами во всех подробностях, не показалась мне особенно жестокой. Признаюсь, - я ожидал еще худшего. Я уже писал Вам, что я почти ни на что не надеюсь и если и предпринимаю какие-либо шаги, то больше для собственного успокоения. Я также писал Вам, что я вполне удовлетворился бы, если бы мне удалось найти какую-либо службу в одном из

${ }^{1}$ Попруженко Михаил Георгиевич. О нем см. выше.

2 Вилинский Сергей Григорьевич (1876-1950) - выпускник историко-филологического факультета (1900), приват-доцент (1904), профессор (1910) русского языка и словесности ИНУ. С 1920 г. в эмиграции в Болгарии. Профессор университета им. Т. Масарика в Брно и Русского педагогического института имена Я. Коменского в Праге.

3 Агура Александр Дмитриевич (1878-1969) - приват-доцент кафедры чистой математики ИНУ. С 1920 г. в эмиграции в Софии (Болгария). В 1920-1969 гг. преподаватель математики в русской гимназии, член Русско-болгарского комитета.

4 Дуван-Хаджи Александр Федорович (Исаак Юфудович, 1886-19??) - высшее образование получил на медицинских факультетах Новороссийского и Юрьевского университетов. С 1918 г. ординатор Одесских высших женских медицинских курсов, с 1920 г. ассистент Одесского медицинского института. С 1922 г. в эмиграции, в Болгарии и Румынии.

5 Трифильев Евгений Парфентьевич (1867-1925) - историк, археолог. Окончил историкофилологический факультет Харьковского университета (1890), приват-доцент (1902-1911). Профессор ИНУ (1911-1920) и ряда других институтов высшей школы Одессы.

${ }^{6}$ В связи с тем, что фамилия А.В. Флоровского часто искажалась в официальных документах, даже в таких документах, как предписание НКВД Губнаробразу об увольнении преподавателей высшей школы Одессы в связи с высылкой за рубеж, на созвучную «Фроловский», то скорее всего под «однофамильцем» подразумевается Фролов Владимир Сергеевич (1888-19??) - минеролог. Выпускник физико-математического факультета ИНУ. В 1921-1922 гг. ассистент Одесского института народного образования.

7 Оксман Юлиан Григорьевич (1894-1970) - историк литературы, пушкинист, литературовед.

8 Бузук Петр Афанасьевич (1891-1938) - филолог, славист. Окончил ИНУ (1916). Преподавал в ряде вузов Одессы. С 1925 г. преподавал в Белорусском университете. С 1931 г. - директор Института языкознания АН БССР.

9 Дложевский Сергей Степанович (1889-1930) - историк, профессор Одесского института народного образования (1920-1930), директор Одесского государственного историко-археологического музея, председатель Одесской комиссии краеведения при ВУАН.

10 Ляпунов Борис Михайлович (1862-1943) - лингвист-славист. Член-корреспондент СанктПетербургской Академии наук (1907), Болгарской (1932) и Чешской (1934) академий наук. Академик АН СССР (1923) и Польской АН (1930).

11 Лазурский Владимир Федорович (1869-1947) - литературовед, историк литературы. Профессор ИНУ и ряда других институтов высшей школы Одессы.

12 Рубинштейн Сергей Леонидович (1889-1960) - философ, психолог. С 1919 г. преподавал в Новороссийском университете и ряде вузов Одессы. Директор Одесской центральной научной библиотеки. Профессор Ленинградского педагогического института (1930-1942), Московского университета (1942-1949). Член-корреспондент АН СССР (1943).

13 Речь идет об издании: Ученые записки Высшей Школы г. Одессы. Отдел гуманитарнообщественных наук / под ред. проф. В.Ф. Лазурского, А.В. Флоровского, М.И. Гордиевского и П.А. Бузука. Одесса, 1922. Т. 2. 
университетских городов Чехии. Эта служба, давая прожиточный минимум, все же не закрывала бы, надеюсь, мне возможности продолжать научные занятия. Неужели и это есть нечто недостижимое? Поймите, дорогой Антоний Васильевич, что полное почти отсутствие научной и вообще культурной атмосферы в Софии (никаких научных или литературных обществ, собраний, докладов) заставляет постепенно замирать ${ }^{1}$, впадать в «мрачность», заниматься высчитыванием грошовых доходов и расходов..., а годы идут... Очень тяжело и, может быть; если бы в финансовом ${ }^{2}$ отношении было легче, то было бы еще тяжелее. Живу в бараках русско-болгарского общежития в общей с учениками комнате «пожираемый» еженощно «дервеницами» (попросту клопами), от которых нет никакого спасения.

По совету Сергея Григорьевича я послал Францевуз curriculum vitae, прошение и письмо, в котором прошу его поддержки. Как пишет мне Сергей Григорьевич, надежд мало. Если можете мне чем-либо помочь, - помогите, дорогой Антоний Васильевич. Плохим питанием, плохим помещением (думаю, что хуже общежития трудно себе что-либо представить) меня нельзя испугать (в Чехии), но перспективой полной невозможности жить умственной жизнью - можно. Все же, м[ожет] б[ыть] по обычной дурацкой человеческой привычке, почему-то не теряю надежды и чего-то жду. О Е. Буницком никаких сведений со времени своего отъезда не имею. Сердечно благодарю Вас за внимание ко мне.

Искренно Вам преданный, Ф. Александров

Адрес: София (Болгария), русское общежитие против Гара, мне.

(Гара - болгарское название вокзала; простите за наивное, м[ожет] б[ыть], объяснение).

АРАН. Ф. 1609. Оп. 2. Д. 114. Л. 3-4об. Автограф.

\title{
№3
}

\section{Письмо Ф.Г. Александрова А.В. Флоровскому. София-Прага. 19 июля 1923 г.}

\author{
19/VII 1923 [года], София
}

Дорогой Антоний Васильевич, -

получив Ваше письмо, направленное в Варну, очень поздно ко мне пришедшее, я немедленно Вам ответил. Недавно получил открытку от проф[ессора] В.Францева, кот[орый] пишет, что лично наводил обо мне справки в Мин[истерстве] иностр[анных] дел и т[ак] к[ак] он говорит, что прежде всего представление должно было пойти от Учебной коллегии 4 (членом которой, как он пишет, он не состоит) и надо чтобы она сделала обо мне представление Мин[истерству] ин[остранных] дел, то я заключаю, что этого заключения коллегии до сих пор нет, между тем как прошение (с приложением 5 curriculum vitae) на имя этой коллегии мною очень давно было через Вас послано и, согласно Вашему ответу, туда направлено Вами. Не будете ли Вы добры, Антоний Васильевич, хотя бы случайно, мимоходом узнать, почему это прошение до сих пор не рассмотрено. Правда, проф[ессор] В. Францев, пишет, что путь этот почти безнадежен, в виду сильных сокращений ассигнований. Недавно читал, что в Праге открывается (вероятно, уже открылся) Русский педагогический институт имени Амоса Коменского ${ }^{6}$ (врем[енный] директор, по газетным

\footnotetext{
${ }^{1}$ В публикации Г.А. Савиной это слово ошибочно указано в кавычках (Савина, 2002: 341).

2 В публикации Г.А. Савиной ошибочно указано слово «...философском...» (Савина, 2002: 341).

3 Францев Владимир Андреевич (1867-1942) - историк и литературовед, академик. До революции профессор Киевского, Варшавского и Донского университетов. В эмиграции профессор Карлова университета в Праге.

4 Учебная коллегия при Комитете по обеспечению образования русских студентов.

5 В публикации Г.А. Савиной ошибочно указано слово «...прилагаемым...» (Савина, 2002: 343 ).

6 Решение об учреждении Русского педагогического института им. Яна Амоса Коменского было принято правлением Союза русских академических групп в сентябре 1922 г., занятия начались с 1 августа 1923 г. В связи с прекращением ассигнований институт был закрыт в начале 1927 г.
} 
сведениям, проф[ессор] Острогорский미. Думаю, что учебные планы этого института (по-видимому, типа учительских институтов) не могли обойтись по крайней мере без курса общего языкознания и даже без курса истории русского языка. А так-как среди высланных нет языковедов, то нельзя ли надеяться на устройство в этом институте? С чувством большой обиды за себя (признаюсь), читал списки многочисленных оставленных для приготовления к проф[ессорскому] званию по кафедрам² Русского юридического факультета. Им, очевидно, можно дать возможность начинать (не продолжать) научные занятия, а уже начавшим и сделавшим еще очень мало можно отказывать в академической помощи. Начавшим уже научно-преподавательскую деятельность ставится на вид (там, где, конечно, это соответствует действительности) малое количество научных работ (как, м[ожет] б[ыть], это делается в отношении меня). Но тогда получается какой-то заколдованный ${ }^{3}$ круг: связи с высшей школой и научными учреждениями не получаешь потому, что имеешь мало научных трудов, а исправить это положение, т[о] е[сть] увеличить количество научных трудов не сможешь именно вследствие отсутствия связи с высшей школой и научными учреждениями.

Не помню, писал ли я Вам, что попытка моя иметь какое-либо формальное отношение к местному университету окончилась неудачей. Я и не делал бы этой попытки, если бы не разговор с одним из здешних профессоров, кот[орый] выяснил мне, что на работу при кафедре сравнит[ельного] яз[ыкознания] и санскрита рассчитывать нельзя (каф[едра] занята Младеновым ${ }^{4}$, отчасти Цоневым 5 ), быть же работником по кафедре 6 классической филологии (лингвистом по классич[еским] языкам) я могу, но в качестве частного доцента (почти бесплатное чтение лекций). По его настоят[ельному] совету я подал прошение. Многие ${ }^{7}$ обещали поддержку. В результате получился отказ по мотиву крайне незнач[ительного] числа (один человек) записавшихся на классич[еское] отделение. Странно то, что количество записавшихся, конечно, было известно и даже упоминалось одним из профессоров в частном со мной и с проф[ессором] Младеновым разговоре. Для чего нужно было проделывать эту комедию обещаний с ведения 8 явно безнадежного дела не знаю. Словом, обычная история «балканских обещаний».

Живу в прежних, как говорят в Одессе, «кошмарных» условиях жизни. Устал и от писания писем, и от надежд, и от разочарований, и от мелких и крупных тревог.

Новых сведений касательно научно-преподавательской жизни нашей милой Одессы не имею. Е. Буницкий до сих пор сидит в Варне со всей своей семьей. По словам недавно видевших его, он выглядит хорошо. Сравнительно недавно только закончился у нас период дождей и начались «софийские жары». извинить.

Вот и все новости. Тяжеловатость9 стиля и некоторую неряшливость почерка прошу

Не откажите же, дорогой Антоний Васильевич, навести просимые мною справки по моему делу.

Искренно преданный Вам, Феодор Александров

София (Болгария), Русское общежитие против Гара, мне.

\footnotetext{
1 Острогорский Сергей Алексеевич (1867-1934) - почетный лейб-медик при дворе Николая II, директор Петербургских курсов им. П.Ф. Лесгафта. В эмиграции - профессор и директор Русского педагогического института им. Я.А. Коменского, член правления Академической группы и председатель Общества русских врачей в Чехословакии (1923-1927).

2 В публикации Г.А. Савиной ошибочно указано слово «...кафедре...» (Савина, 2002: 343).

3 В публикации Г.А. Савиной ошибочно указано слово «...замкнутый...» (Савина, 2002: 343).

4 Стефан Младенов Стоянов (1880-1963) - болгарский языковед; профессор Софийского университета (1921-1941). Академик Болгарской Академии наук (1924) и член-корреспондент АН CCCP (1929).

5 Цонев Беньо Стефанов (1863-1926) - болгарский языковед. Профессор Софийского университета, академик Болгарской Академии наук (1900).

6 В публикации Г.А. Савиной ошибочно указано слово «...части...» (Савина, 2002: 344$).$

7 В публикации Г.А. Савиной ошибочно указано слово «Мне...» (Савина, 2002: 344).

8 В публикации Г.А. Савиной ошибочно указана фраза «...и всего...» (Савина, 2002: 344).

9 В публикации Г.А. Савиной ошибочно указано слово «Тяжеловатости...» (Савина, 2002: 344).
} 

города.

P.S. Адрес свободно можно писать по-русски, за исключ[ением], пожалуй, названия

Сообщите, пожалуйста, адрес Дмитрия Павловича Кишенскогоํ.

Ф.A.

АРАН. Ф. 1609. Оп. 2. Д. 114. Л. 5-5об. Автограф.

№4

\section{Письмо Ф.Г. Александрова А.В. Флоровскому. София-Прага.} 3 января 1924 г.

\section{3/I - [19]24 [года], София}

Дорогой Антоний Васильевич, -

недавно я получил от С.Г. Вилинского открытку, в которой он мне сообщает, что, проездом в Прагу, у него был проф. Д.Н. Вергун ${ }^{2}$, который, между прочим, сообщил, что мое дело рассматривалось в коллегии, что отношение было благожелательное, что я, как сравнительный языковед, желателен для русского филологического факультета в Праге, но что беда только в отсутствии у меня работ. Однако, насколько мне помнится, в посланном Вам curriculum vitae я говорил не только о медальной своей работе и маленькой статейке в сборнике в честь Б.М. Ляпунова, но и о работах, готовых к печати, каковыми являются: 1) Курс сравнительной грамматики индоевропейских языков. Фонетика. Морфология; 2) Очерк исторической фонетики латинского языка. Лекции, читанные на Педагогических курсах.

Скорее во исполнение предложения С.Г. Вилинского, чем с верой в какой-либо успех, сообщаю эти сведенья Вам как декану русского филологического факультета в Праге.

В Берлин (в Русский научный институт) ехать не могу, в виду крайне тяжелых условий жизни там и в виду незначительного содержания (мне нужно помогать оставшейся в России матери). Если Вы пожелали бы сообщить мне что-либо по моему делу, - был бы, конечно, очень благодарен.

Преданный Вам, Феодор Александров

Адрес: София (Болгария), улица Витоша, угол Аспарух, русская гимназия, мне.

АРАН. Ф. 16о9. Оп. 2. Д. 114. Л. 6-7. Автограф.

\section{№5}

\section{Письмо Ф.Г. Александрова А.В. Флоровскому. София-Прага. 2 ноября 1926 г.}

2/XI - [19]26 [года], София

Дорогой Антоний Васильевич,

сравнительно с другими пражанами, Вам я менее надоедал, а потому решаюсь обратиться к Вам с большой просьбой; с таковой просьбой я обращался летом к Георгию Васильевичу, и мне стыдно его опять беспокоить.

\footnotetext{
1 Кишенский Дмитрий Павлович (1858-1933). Окончил медицинский факультет Московского университета (1883). Профессор (1902-1919), ректор (1913-1917) ИНУ. С 1919 г. в эмиграции. В Королевстве сербов, хорватов и словенцев (1919-1923), Чехословакии (1923-1933), Председатель медицинской комиссии при комитете по обеспечению образования студентам из России.

${ }^{2}$ Вергун Дмитрий Николаевич (1871-1951) - философ. В 1918 г. приват-доцент Московского, позднее профессор Иркутского университетов. С 1922 г. - преподаватель Высшей школы в Праге, с 1945 профессор университета в Хьюстоне (США).

3 Флоровский Георгий Васильевич (1893-1979) - выпускник (1916), приват-доцент (1919-1920) ИНУ. С 1920 г. в эмиграции. Профессор кафедры патрологии богословского института в Париже, церковной истории и славистики Гарвардского и Принстонского университетов.
} 
Приехавшая ко мне в прошлом году мать должна непременно продлить свой заграничный паспорт. Паспорт выдан на год. Так как срок его истекал 25 мая 1926 года, то я исхлопотал продление на полгода, так что срок паспорта истекает 25 ноября 1926 г.

Теперь необходимо продлить паспорт еще на год. Очень прошу Вас, Антоний Васильевич, помочь мне в этом деле. Георгий Васильевич, который мне помог в первом продлении, поручал (за изв[естное] вознаграждение) какому-то надежному лицу, кажется, студенту, отнести прошение, паспорт и деньги в представительство. Может быть, и Вы, спросив, если найдете удобным, об этом лице у Георгия Васильевича, смогли бы поручить этому же лицу вновь произвести известную уже ему операцию, т.е. отнести все необходимое в правительство и получить продленный паспорт обратно.

Может быть, можно паспорт, прошение и деньги переслать ценным, с описью, пакетом прямо в представительство. Словом, поступайте так, как найдете для себя удобным и надежным в смысле сохранности денег (не попасть бы на «стрелка», как теперь выражаются) и в смысле отсутствия затяжки дела (ныне высылаю паспорт за месяц до истечения срока; летом я запоздал и уплатил большой штраф).

Деньги (6о0 крон; исхожу из 297 крон, взятых, как отмечено на паспорте, за полугодовое продление; сверх этих 297 крон взяли еще 250 крон, но за просрочку двух месяцев, как штраф) высылаю через два дня ценным пакетом. Паспорт и прошение прилагаю. Совершенно искренно прошу Вас простить мне причиняемое Вам беспокойство. Очень прошу Вас не отказать мне в моей просьбе, помочь мне и обещаю, что больше уже не буду беспокоить ни Вас, ни Георгия Васильевича.

Адрес: София (Болгария), Булевард Христо Ботев, № 63.

Преданный Вам, Ф. Александров

P.S. Прилагаю мамин загр[аничный] паспорт и прошение. Ни Клавдия Васильевна', ни Мих[аил] Георг[иевич]2 не знают Вашего личного адреса, а потому пишу на «Комитет». Адрес Комитета дали мне тоже приблизительный. От прошлой операции, как мне писал Георгий Васильевич, осталось крон 20, каковыми, если это достаточно, можно расплатиться с лицом, которое произведет эту операцию. Если нужны еще деньги, немедленно мне сообщите, дабы я не упустил срока. Очень прошу Вас ответить мне на это письмо, хотя бы открыткой. От Кл[авдии] Вас[ильевны] узнал, что Г[еоргий] В[асильевич] есть в Праге.

Ф.A.

АРАН. Ф. 1609. Оп. 2. Д. 114. Л. 8-9об. Автограф.

№6

\section{Письмо Ф.Г. Александрова А.В. Флоровскому. София-Прага. 5 ноября 1926 г.}

$$
\text { 5/XI - [19]26 [года], София }
$$

Дорогой Антоний Васильевич,

2/XI выслал Вам заказным мамин заграничный паспорт и прошение. Настоящим пакетом высылаю Вам 620 крон (АC 458408, АC 796141, В 836614, Н 495382, V 760930, $\mathrm{W} 697835$ = №№ банкнот по 100 кр[он]; C 309449, С. 918133 = №№ бан[кнот] по 10 крон). Еще раз очень прошу Вас помочь мне и переслать прошение, паспорт и деньги в представительство на предмет продления паспорта на год. К сожалению, Георгия Васильевича нет сейчас в Праге, и потому Вы не можете узнать, какой именно студент проделал для меня эту операцию прошлый раз. Впрочем, припоминаю, что об окончательной стоимости продления справлялся, если не ошибаюсь, студент Карпинский.

\footnotetext{
1 Флоровская Клавдия Васильевна (1883-1965) - окончила Петербургские высшие женские курсы (1909). Внештатный преподаватель (1917-1919), приват-доцент (1919-1920) Одесских высших женских курсов и приват-доцент ИНУ (1919-1920). С 1920 г. в эмиграции в Болгарии, преподаватель русского и латинского языков, истории в гимназиях Софии (1920-1945).

2 Попруженко М.Г. О нем см. выше.
} 
Может быть и всю операцию проделал тогда именно он. Будьте добры, спросите его об этом, если не найдете какое-либо другое, подходящее лицо. И прошлое письмо, и этот денежный пакет посылаю (не без некоторого страха) по адресу комитета, ибо личного Вашего адреса ни я, ни Ваши родные не знают.

О получении этого пакета и прошлого очень прошу Вас сообщите мне открыткой.

Вновь выражаю искренние извинения за причиняемые беспокойство.

Преданный Вам, Ф. Александров

София (Болгария), Булевард Хр[исто] Ботев, № 63.

P.S. Добавил 20 крон, кот[орые] вместе с остатком (20-25 кр[он]) от прошлой операции послужат на покрытие расходов: оплата труда Карпинского, или кого другого, почт[овые] расходы и т[ак] д[алее].

Ф.A. АРАН. Ф.1609. Оп. 2. Д. 114. Л. 10-10об. Автограф.

№7

\section{Письмо Ф.Г. Александрова А.В. Флоровскому. София-Прага. 17 декабря 1926 г.}

$$
\text { 17/XII - [19]26 [года], София }
$$

Дорогой Антоний Васильевич,

получил мамин продленный паспорт со всеми приложениями. Мама прямо растрогана оказанной ей Вами помощью, сердечно Вас благодарит и просит Бога хранить Ваше здоровье.

O себе сообщаю следующее. Обратился (м[ожет] б[ыть] на всегда) в преподавателя латинского языка средней школы. Преподаю в трех учебных заведениях и потому занят до крайности. Весь день разбит совершенно: утром - в болг[арскую] гимназию, после обеда опять в болг[арскую] гимн[азию] (II-ая смена), после чего - в русскую; кроме того, два раза в неделю - в семинарию.

Если принять во внимание, что надо еще готовится к урокам (переводы лат[инских] авторов) и поправлять тетради, то станет ясно, что ни о каком продолжении научной работы во всяком случае в теч[ение] уч[ебного] года не может быть и речи. Не иметь такой массы уроков - очень заманчиво, но и опасно. Впрочем, сама судьба постоянно нас, чужденцев разгружает от работы. Известное Вам сокращение пражских кредитов значительно отразится на сети русских учебн[ых] зав[едениях] в Болгарии: с будущего года две средних школы, вероятно, будут сокращены. Наша гимназия, как столичная, возможно, и сохранится, особенно если родители и русская колония будут проявлять регулярные денежные усилия (регулярная плата за учение в необходимом размере).

Могу еще сообщить о себе, что имел дерзость участвовать в конкурсе на должность лектора русского языка в университете и провалился, ибо победила национальная кандидатура.

O наших бывших коллегах ничего особенного, нового не слыхал. Дочь Мулюкина писала ему, между прочим, что Варнеке 2 сильно постарел и совсем опустился. Бузук перевелся в белорусский университет. Вот и все то скудное, чем я располагаю.

А.С. Мулюкин всегда бодр и весел.

В заключение скажу, что я, памятуя о тяжелой участи многих русских вообще, доволен своей судьбой и благодарен ей за даваемые ею радости и блага.

Примите, дорогой Антоний Васильевич, и от меня сердечную благодарность за оказанную нам помощь и за внимание ко мне.

\footnotetext{
${ }^{1}$ Мулюкин Александр Сергеевич (1873-1953) - выпускник юридического факультета Петербургского университета. Профессор ИНУ (1910-1920) и ряда вузов Одессы. С 1922 г. в эмиграции. Вел частную юридическую практику в Софии.

${ }^{2}$ Варнеке Борис Васильевич (1874-1944) - филолог-классик, историк театра. Заслуженный деятель науки УССР (1941).
} 
С большой радостью принимаю Ваше предложение писать Вам.

Преданный Вам, Ф. Александров

АРАН. Ф. 16о9. Оп. 2. Д. 114. Л. 11-12. Автограф.

№8

\section{Письмо Ф.Г. Александрова А.В. Флоровскому. София-Прага. 18 ноября 1927 г.}

18/XI - [19]27 [года], София

Дорогой Антоний Васильевич,

вопреки своему прошлогоднему обещанию, силою обстоятельств я вынужден опять беспокоить Вас покорнейшей просьбой переслать прошение, деньги и мамин паспорт в полномочное представительство для продления еще на год. Мое прошлогоднее обещание больше Вас не беспокоить было совершенно правдивым, ибо мать должна была вернутся на родину летом этого года. Человеку в ее возрасте, к тому же постоянно болеющему, оказалось невозможным: помириться с мыслью доживать остаток жизни и, м[ожет] б[ыть], умереть на чужой земле; в этом смысле отправляясь сюда, она не рассчитала своих душевных сил.

Однако, тяжелая болезнь (воспаление желчных путей), постигшая ее в конец лета, волокита с турецким разрешением (транзит через Конст[антинополь]), невозможность найти сопровождающее лицо (меня в Конст[антинополь] не пускают) - заставили отложить ее отъезд до следующего лета.

Поверьте, дорогой Антоний Васильевич, что мне очень тяжело Вас беспокоить вторично столь хлопотливым делом, но и теперь утверждаю, что делаю это только потому, что мне не к кому обратиться.

Сердечно прошу Вас не отказать мне в помощи.

Если нельзя найти человека, который бы проделал это за вознаграждение, то м.б. можно проделать все это путем городской почты.

В настоящем письме пересылаю мамин паспорт, прошение и 30 крон на первые почтовые расходы.

Срок паспорта истекает 25 ноября. Деньги на продление (за прошлогоднее продление взяли 577,5 крон) и на расходы по ведению дела высылаю сегодня же денежным пакетом.

Если бы денежный пакет пришел случайно позже 25 ноября (кажется, с денежными пакетами происходит большая проволочка), то очень прошу Вас переправить паспорт и прошение в представительство, не ожидая денег (хотя бы точно 25-го), дабы не был наложен штраф за просрочку.

Покорнейше прошу простить причиненное Вам беспокойство.

София (Болгария), улица Венелин, № 11 (нов).

С искренним уважением, Ваш $\Phi$. Александров

АРАН.Ф.1609. Оп. 2. Д. 114. Л.13-14. Автограф.

№9

\section{Письмо Ф.Г. Александрова А.В. Флоровскому. София-Прага. 18 ноября 1927 г.}

18/XI 1927 [года], София

Дорогой Антоний Васильевич,

одновременно с заказным письмом, включающим мою просьбу к Вам, мамин паспорт и прошение в полномочное представительство, посылаю и этот денежный пакет с 600 чешск[ими] крон[ами]. Судя по прошлогоднему, за продление на год необходимо 
уплатить 577,5 крон. Остаток в 22,5 кр[он] вместе с 30 крон[ами], посылаемыми заказным письмом, составят сумму, думаю, достаточную для оплаты труда взявшегося все проделать.

Пользуюсь случаем и здесь искренно просить у Вас прощения за причиняемое большое беспокойство.

София (Болгария), ул. Венелин, № 11 (нов).

Всегда готовый к услугам,

Ваш Ф. Александров

АРАН. Ф. 1609. Оп. 2. Д. 114. Л. 15. Автограф.

№10

Письмо Ф.Г. Александрова А.В. Флоровскому. София-Прага. 2 января 1928 г.

2/XII ${ }^{1}-[19] 28$ [года], София

Дорогой Антоний Васильевич,

уже более месяца тому назад переслал Вам мамин паспорт и деньги (6оo крон), убедительно прося Вас в последний раз помочь мне, переслать паспорт и деньги за продление его по назначению. Меня очень беспокоит судьба всего дела. Если деньги пропали (м[ожет] быть попался недобросовестный передатчик), то пишите немедленно, ибо несвоевременная подача паспорта и денег грозит мне большими расходами (штраф за просрочку).

Еще раз совершенно искренно и покорнейше прошу Вас простить мне причиняемое Вам большое беспокойство.

Благоволите принять наилучшие пожелания к Новому Году и празднику Рождества Христова.

Преданный Вам,

София, улица Венелин, №11, кв[артира] Стефанова.

Ф. Александров

АРАН. Ф. 16о9. Оп. 2. Д. 114. Л. 17-17об. Автограф.

№11

\section{Письмо Ф.Г. Александрова А.В. Флоровскому. София-Прага. 29 января 1928 г.}

29/I - 1928 [года], София

Дорогой Антоний Васильевич,

убедительнейше прошу Вас ответить мне, что случилось с моим делом. После отсылки Вам маминого паспорта и денег для уплаты за его продление, я спрашивал Вас о судьбе моего ходатайства письмом, отправленным в январе месяце. До сих пор нет никакого ответа. Я очень беспокоюсь. Ради Бога ответьте, получили ли Вы мамин паспорт и деньги и передано ли все это в представительство.

Mое беспокойство, думаю, извинительно, ибо потеря документа или большая просрочка грозят мне очень большими расходами.

Как всегда, искренно прошу Вас простить причиняемое беспокойство.

София (Болгария), Венелин, № 11 (нов).

Ваш Ф. Александров

АРАН. Ф. 16о9. Оп. 2. Д. 114. Л. 16-16об. Автограф.

${ }^{1}$ Месяц декабрь указан ошибочно. Исходя из содержания письма оно было написано в январе 1928 г. 


\section{№12}

\section{Письмо Ф.Г. Александрова А.В. Флоровскому. София-Прага. 2 августа 1961 г.}

София, 2 августа 1961 г[ода].

Дорогой Антоний Васильевич,

только к концу своей жизни я смог включиться в научную работу при Софийском университете, где я как преподаватель проработал свыше восьми лет.

В сборнике Болгарской Академии наук, составленном к IV-му конгрессу славистов в Москве $^{1}$, помещена и моя маленькая статья (стр[аница] 145 и далее ${ }^{2}$ ). В ней я стараюсь выяснить одно из важных явлений синтаксиса старославянского (здесь придерживаются термина - «древнеболгарского») языка. Разъяснение этого явления тесно связано с разъяснением сходного явления в древнерусском языке и в языке древних памятников других славянских языков.

Я был бы чрезвычайно Вам благодарен, если бы Вы согласились передать проф[ессору] Гавранеку³ оттиск моей статьи с убедительной моей просьбой высказаться о ней печатно или хотя бы в частном порядке через Вас. Хотя указанный сборник, наверно, имеется в библиотеке Пражского университета, я все же предпочел бы переслать ему правленный мною оттиск, так как при спешном печатании сборника допущено очень много серьезных опечаток. Если Вы, дорогой Антоний Васильевич, согласитесь мне помочь, то по получении от Вас ответа я немедленно перешлю Вам оттиски заказной бандеролью.

Профессор Гавранек приезжал к нам в Софию; я слушал его доклад по вопросам, относящимся к старославянскому языку, и потому думаю, что лучше всего будет передать мою статью для отзыва именно ему. Если же я ошибаюсь, то прошу Вас передать ее (с той же моей просьбой) тому специалисту, который занимается вопроса ми синтаксиса старославянского языка или вообще славянских языков в Пражском университете. У нас здесь больше разрабатываются вопросы морфологии и фонетики древнеболгарского языка.

Буду крайне Вам благодарен за оказанную мне помощь.

С искренним к Вам уважением и сердечными пожеланиями, Ваш Ф. Александров

Адрес: Болгария, София, ул[ица] Клемент Готвальд, 40, Александрову Федору Георгиевичу.

АРАН. Ф. 1609. Оп. 2. Д. 317. Л. 77-77об. Автограф.

\section{№13}

\section{Письмо Ф.Г. Александрова А.В. Флоровскому. София-Прага. 28 августа 1961 г.}

София, 28 августа 1961 г[ода].

Дорогой Антоний Васильевич,

получил Ваше первое и второе письмо. Сердечно Вас благодарю за внимание и доброе ко мне отношение. 15/Х-го выслал заказной бандеролью на Ваш адрес четыре оттиска своей статьи с соответствующими надписями. Во всех экземплярах нанесены поправки. При отпечатании, как видите, допустили очень много ошибок, и только по этим соображениям я просил бы Вас один из экземпляров (он надписан карандашом) передать (если это удобно и возможно) в библиотеку Вашего университета.

\footnotetext{
${ }^{1}$ IV международный конгресс славистов в Москве проходил в 1958 г.

2 Александров Ф.Г. О значениях и функциях местоимений «который», «иже» и «кый» в основных памятниках древноболгарского языка // Славистичен сборник. По случай IV международен конгрес на славистите в Москва. Т. 1. София, 1958. С. 145-163.

3 Гавранек Богуслав (1893-1978) - чехословацкий языковед, филолог-славист. С 1945 г. профессор Карлова университета; с 1952 г. - академик Чехословацкой Академии наук. В 1953-1961 гг. - ректор Высшей школы русского языка и литературы в Праге.
} 
Меня несколько смутило то обстоятельство, что проф[ессор] Курцํㅜ, делая оценку моей статьи, ничего не сказал по поводу самого для меня важного: правильно ли я выясняю замену в старославянском языке старого обычно средства выражения относительной связи предложений (местоимения «иже») новым средством (местоимением «кый»)?

Хочется мне попросить Вас, Антоний Васильевич, предупредить и проф[ессора] Гавранека, и проф[ессора] Досталя ${ }^{2}$, что употребленный мною термин «древноболгарский язык» является отражением воспринятого в нашей болгарской академической среде термина «старобългарски език». Что касается недостаточного использования мною материалов по старославянскому языку, то, во-первых, статья своим заглавием предупреждает о неполном использовании всех памятников, а во-вторых, от количества примеров не зависит правильность предложенного объяснения. Я, конечно, сильно отстал от современного состояния славянского и русского языкознания (менее отстал от современного состояния общего и сравнительного индоевропейского языкознания), что вполне понятно; ведь «вернулся» я к своей научной работе и к научной работе в смежных отделах только к концу жизни, после длительного перерыва протяжением почти в тридцать лет. Да и вернулся я к науке по счастливой случайности: факультет возложил на меня ведение практических занятий со студентами-русистами по исторической грамматике русского языка - сроком до возвращения из Советского Союза посланного туда болгарского кандидата. В процессе занятий я заинтересовался вопросом о способах выражения относительного (определительного) подчинения в древнерусском языке. Вопрос оказался трудным и обширным. Пришлось ограничить себя, обратившись к старославянскому языку, где это явление выступает не в такой сложности, как в других славянских языках. Вопросами древнерусского синтаксиса и синтаксиса славянских языков здесь никто не занимается, и в этом смысле мне никто не может дать некоторых методологических и методических указаний. Основная советская научная литература мне известна, но при чтении этих работ у меня возникает много вопросов, на которые можно было бы получить ответы только при личном контакте. Несколько очень нужных мне исследований не могу достать, так как они хранятся в виде авторефератов кандидатских диссертаций. Кстати, кто там у Вас в Праге или вообще в Чехии работает в области древнерусского языка? Нельзя ли было бы с Вашей помощью связаться с кем-нибудь из этих специалистов или специалистов по сравнит[ельной] граммат[ике] слав[янских] языков с целью обмена мнениями по трудным, еще не разрешенным вопросам?

Простите, дорогой Антоний Васильевич, что я Вам «морочу голову», но я чувствую необходимость получить какой-то толчок из вне, чтобы выйти, вырваться из некоторых тупиков, в которые я зашел, не находя нужных мне разъяснений.

Несколько слов о людях нашего поколения. Если иметь в виду наше поколение в специфическом значении, то, действительно, никого уже в живых нет. В свое время сюда переехал из Сербии проф[ессор] Малинин ${ }^{3}$ с семьей, но пришлось ему тут работать в качестве преподавателя по русскому языку в средней школе. На медицинском факультете работает сын проф[ессора] Завьялова4 ${ }^{4}$ Вот, кажется, и все.

Скажу несколько слов о себе (подробней - в следующем письме). Как Вы знаете, моя мать переехала ко мне в 1925 году; прожила она, тяжело болея печенью, до 1938 года. В 1941 году я женился. У меня сын; он уже в 10-м классе. Хотелось бы дожить до окончания им образования и вступления в самостоятельную жизнь.

\footnotetext{
${ }^{1}$ Курц Иожеф (1901-1972) - чехословацкий языковед, славист. Профессор Карлова университета.

2 Досталь Антонин - чешский языковед.

3 Малинин Иван Михайлович (1883-1961) - педагог, психолог. Выпускник историкофилологического факультета (1908), приват-доцент (1912), доцент (1916-1919) ИНУ, лектор Одесских высших женских курсах и Одесской консерватории, попечитель Одесского учебного округа (19171919). С 1920 г. в эмиграции. Директор русской мужской гимназии в Белграде (1925-1941). Председатель Общества преподавателей русских учебных заведений в Королевстве сербов, хорватов и словенцев.

4 Завьялов Василий Васильевич (1873-1930) - окончил медицинский факультет Московского университета (1895). В 1899 г. защитил докторскую диссертацию. Приват-доцент (1901), профессор (1902) ИНУ. С 1920 г. в эмиграции, профессор Софийского университета (1920-1930).
} 
Искренне желаю Вам крепкого здоровья и радостных успехов в научной работе.

Ваш Ф. Александров

АРАН. Ф. 1609. Оп. 2. Д. 317. Л. 79-80. Автограф.

\section{Литература}

Аксенова, 1994 - Аксенова Е.П. Из переписки Г.В. Вернадского и А.В. Флоровского // Славяноведение. 1994. № 4. С. 92-101.

Аксенова, 1995 - Аксенова Е.П. К истории русской научной эмиграции в Югославии: письма А.Л. Погодина А.В. Флоровскому // Славяноведение. 1995. № 4. С. 78-83.

Аксенова, 1998 - Аксенова Е.П. Из переписки В.А. Мошина и А.В. Флоровского // Русь и южные славяне. СПб.: Алетейя, 1998. С. 134-143.

АРАН - Архив Российской академии наук

Василь Терентійович Галяс, 2006 - Василь Терентійович Галяс (біографічні матеріали до 85-річчя з дня народження) / Упорядник В.М. Хмарський. Одеса: Гермес, 2006. 84 с.

Галчева, Голубович, 2015 - Галчева Т.Н., Голубович И.В. «Понемногу приспособляюсь к „независящим обстоятельствам“». П.М. Бицилли и семья Флоровских в первые годы эмиграции. София: Изд-во Солнце, 2015. 320 с.

ГАОО - Государственный архив Одесской области

Душенко, 2003 - Душенко К.В. Большая книга афоризмов. Изд. 7-е, испр. М.: Изд-во Эксмо, 2003. 1055 с.

Ковалев, 2011 - Ковалев М.В. «Многоуважаемый Профессор Антоний Васильевич!» (к публикации писем С.Г. Пушкарева к А.В. Флоровскому) // Mup историка: историографический сборник. Омск: Изд-во Омского госуниверситета, 2011. Вып. 7. С. 486-495.

Ковалев, 2015 - Ковалев М.В. А.В. Флоровский и его немецкие корреспонденты // Историческая память и стратегии российско-немецкого межкультурного диалога / Под ред. М.В.Ковалева и И.Р. Плеве. Саратов: Саратовский государственный технический университет имени Ю.А. Гагарина, 2015. С. 136-183.

Косик, 2008 - Косик В.И. Софии русский уголок. Очерки со стихами о русских, покинувших Россию после октябрьской революции 1917 года и последовавшей за ней гражданской войной. М.: ПРОБЕЛ-2000, 2008. 236 с.

Лаптева, 2017 - Лаптева Т.Н. Личный фонд историка-эмигранта А.В. Флоровского в Архиве Российской академии наук: научное использование и реконструкция: дисс... канд. ист. наук. М., 2017. 323 с.

Левченко, 2008 - Левченко В.В. «Философский пароход»: к вопросу о депортации одесских ученых в 1922 г. // Проблемы славяноведения. Брянск: ООО «Ладомир», 2008. Вып. 10. С. 125-137.

Левченко, 2010 - Левченко В.В. Історія Одеського інституту народної освіти (1920-1930 pp.): позитивний досвід невдалого експерименту / Відп. ред. В.М. Хмарський; наук. ред. Т.М. Попова. Одеса: ТЕС, 2010. 428 с.

Левченко, 2014 - Левченко В.В. Одесские ученые в условиях российской эмиграции первой волны: пути, адаптация, судьбы // Мир глазами историка: памяти академика Юрия Александровича Полякова. М.: ИРИ РАН, 2014. С. 139-156.

Левченко, 2016 - Левченко В.В. В пучине первой волны российской эмиграции: судьбы одесских ученых-историков и последствия для исторической науки // Российское научное зарубежье: люди, труды, институции, архивы: сб. науч. тр. М.: ИРИ РАН, 2016. С. 160-171.

Музичко, 2011 - Музичко O.Є. Історико-філологічні кабінети у структурі вищої освіти в Одесі наприкінці XIX - першій третині XX ст. // Вісник ОНУ. Бібліотекознавство, бібліографознавство, книгознавство. Т. 16, вип. 1/2 (5/6). 2011. С. 253-268.

Савина, 2002 - Савина Г.А. «Пусть барахтаются...» (К истории «одесской высылки» за рубежом) // Диаспора: Новые материалы. Вып. 3. Париж - СПб.: Athenaeum - Феникс, 2002. С. 293-410.

Фролов, 2019 - Фролов М.А. «Дух бодр и охота к работе прежняя...». Из переписки Ю.Г. Оксмана и А.В. Флоровского (1962-1968) // Emigrantika и возле: К 6о-летию Олега Коростелева / Ред.-сост. Е.Р. Пономарев, М. Шруба. М.: Изд-во «Дмитрий Сечин», Литфакт, 2019. С. $617-652$. 
Levchenko, 2013 - Levchenko V.V. Odessa Scientists as the Passengers of «The Philosophy Steamer» // Bylye gody. 2013. 1 (27): 111-119.

\section{References}

Aksenova, 1994 - Aksenova, E.P. (1994). Iz perepiski G.V. Vernadskogo i A.V. Florovskogo [From the correspondence of G.V. Vernadsky and A.V. Florovsky]. Slavyanovedenie. 4: 92-101. [in Russian]

Aksenova, 1995 - Aksenova, E.P. (1995). K istorii russkoi nauchnoi emigratsii v Yugoslavii: pis'ma A.L. Pogodina A.V. Florovskomu [On the history of the Russian scientific emigration in Yugoslavia: A.L. Pogodin's letters to A.V. Florovsky]. Slavyanovedenie. 4: 78-83. [in Russian]

Aksenova, 1998 - Aksenova, E.P. (1998). Iz perepiski V.A. Moshina i A.V. Florovskogo [From the correspondence of V.A. Moshin and A.V. Florovsky]. Rus' i yuzhnye slavyane. SPb.: Aleteiya. Pp. 134-143. [in Russian]

ARAN - Arkhiv Rossiiskoi akademii nauk [Archive of the Russian Academy of Sciences].

Vasil' Terentiiovich Galyas, 2006 - Vasil' Terentiiovich Galyas (biografichni materiali do 85-richchya z dnya narodzhennya) [Vasyl Terentiyovych Halyas (biographical materials dedicated to the 85th anniversary of his birth)] Uporyadnik V.M. Khmars'kii. Odesa: Germes, 2006. 84 p. [in Ukrainian]

Galcheva, Golubovich, 2015 - Galcheva, T.N., Golubovich, I.V. (2015). «Ponemnogu prisposoblyayus' k „nezavisyashchim obstoyatel'stvam“». P.M. Bitsilli i sem'ya Florovskikh v pervye gody emigratsii ["I am gradually adjusting to 'independent circumstances'". P.M. Bitsilli and the Florovsky family in the early years of emigration]. Sofiya: Izd-vo Solntse, 320 p. [in Russian]

GAOO - Gosudarstvennyi arkhiv Odesskoi oblasti [State Archives of Odessa Region].

Dushenko, 2003 - Dushenko, K.V. (2003). Bol'shaya kniga aforizmov [Big book of aphorisms]. Izd. 7-e, ispr. M.: Izd-vo Eksmo, 1055 p. [in Russian]

Kovalev, 2011 - Kovalev, M.V. (2011). «Mnogouvazhaemyi Professor Antonii Vasil'evich!» (k publikatsii pisem S.G. Pushkareva k A.V. Florovskomu) [“Dear Professor Anthony Vasilievich!” (to the publication of letters from S.G. Pushkarev to A.V. Florovsky)]. Mir istorika: istoriograficheskii sbornik. Omsk: Izd-vo Omskogo gosuniversiteta. Vyp. 7. Pp. 486-495. [in Russian]

Kovalev, 2015 - Kovalev, M.V. (2015). A.V. Florovskii i ego nemetskie korrespondenty [A.V. Florovsky and his German correspondents]. Istoricheskaya pamyat' i strategii rossiiskonemetskogo mezhkul'turnogo dialoga. Pod red. M.V. Kovaleva i I.R. Pleve. Saratov: Saratovskii gosudarstvennyi tekhnicheskii universitet imeni Yu.A. Gagarina. Pp. 136-183. [in Russian]

Kosik, 2008 - Kosik, V.I. (2008). Sofii russkii ugolok. Ocherki so stikhami o russkikh, pokinuvshikh Rossiyu posle oktyabr'skoi revolyutsii 1917 goda i posledovavshei za nei grazhdanskoi voinoi [Sofia's Russian corner. Essays with poetry about Russians who left Russia after the October revolution of 1917 and the civil war that followed]. M.: PROBEL-2000, 236 p. [in Russian]

Lapteva, 2017 - Lapteva, T.N. (2017). Lichnyi fond istorika-emigranta A.V. Florovskogo v Arkhive Rossiiskoi akademii nauk: nauchnoe ispol'zovanie i rekonstruktsiya [The personal fund of the émigré historian A.V. Florovsky in the Archives of the Russian Academy of Sciences: scientific use and reconstruction]: disc... kand. ist. nauk. M., 323 p. [in Russian]

Levchenko, 2008 - Levchenko, V.V. (2008). "Filosofskii parokhod»: k voprosu o deportatsii odesskikh uchenykh v 1922 g. ["Philosophical steamer": on the issue of the deportation of Odessa scientists in 1922]. Problemy slavyanovedeniya. Bryansk: OOO «Ladomir». 10: 125-137. [in Russian]

Levchenko, 2010 - Levchenko, V.V. (2010). Istoriya Odes'kogo institutu narodnoï osviti (1920-1930 rr.): pozitivnii dosvid nevdalogo eksperimentu [History of the Odessa Institute of Public Education (1920-1930): a positive experience of a failed experiment]. Vidp. red. V.M. Khmars'kii; nauk. red. T.M. Popova. Odesa: TES, 2010. 428 s. [in Russian]

Levchenko, 2013 - Levchenko, V.V. (2013). Odessa Scientists as the Passengers of «The Philosophy Steamer». Bylye gody. 1 (27): 111-119.

Levchenko, 2014 - Levchenko, V.V. (2014). Odesskie uchenye v usloviyakh rossiiskoi emigratsii pervoi volny: puti, adaptatsiya, sud'by [Odessa scientists in the conditions of Russian emigration of the first wave: ways, adaptation, destinies]. Mir glazami istorika: pamyati akademika Yuriya Aleksandrovicha Polyakova. M.: IRI RAN, 2014. Pp. 139-156. [in Russian] 
Levchenko, 2016 - Levchenko, V.V. (2016). V puchine pervoi volny rossiiskoi emigratsii: sud'by odesskikh uchenykh-istorikov i posledstviya dlya istoricheskoi nauki [In the abyss of the first wave of Russian emigration: the fate of Odessa historians and consequences for historical science]. Rossiiskoe nauchnoe zarubezh'e: lyudi, trudy, institutsii, arkhivy: sb. nauch. tr. M.: IRI RAN. Pp. 160-171. [in Russian]

Muzichko, 2011 - Muzichko, O.E. (2011). Istoriko-filologichni kabineti u strukturi vishchoï osviti v Odesi naprikintsi XIX - pershii tretini XX st. [Historical and philological offices in the structure of higher education in Odessa in the late nineteenth - first third of the twentieth century.]. Visnik ONU. Bibliotekoznavstvo, bibliografoznavstvo, knigoznavstvo. T. 16, vip. 1/2 (5/6). Pp. 253-268. [in Ukrainian]

Savina, 2002 - Savina, G.A. (2002). «Pust' barakhtayutsya...» (K istorii «odesskoi vysylki» za rubezhom) ["Let them flounder..." (To the history of the "Odessa deportation" abroad)]. Diaspora: Novye materialy. Vyp. 3. Parizh - SPb.: Athenaeum - Feniks. Pp. 293-410. [in Russian]

Frolov, 2019 - Frolov, M.A. (2019). «Dukh bodr i okhota k rabote prezhnyaya...». Iz perepiski Yu.G. Oksmana i A.V. Florovskogo (1962-1968) ["The spirit is cheerful and the desire for work is the same...”. From the correspondence of Yu.G. Oksman and A.V. Florovsky (19621968)]. Emigrantika i vozle: K 6o-letiyu Olega Korosteleva. Red.-sost. E.R. Ponomarev, M. Shruba. M.: Izd-vo «Dmitrii Sechin», Litfakt. Pp. 617-652. [in Russian]

\section{Из истории русского зарубежья: письма Ф.Г. Александрова А.В. Флоровскому}

\section{Валерий Валерьевич Левченко ${ }^{\text {a }}$}

a Одесский национальный морской университет, Украина

Аннотация: В статье опубликованы 13 писем русского ученого-эмигранта Ф.Г. Александрова к А.В. Флоровскому. Они помогают осветить многие стороны жизни русских ученых-эмигрантов в Болгарии в 1920-е и 1960-е гг. В переписке отражены некоторые аспекты культурных и общественных событий русского зарубежья. Среди прочих особый интерес представляют обсуждение вопросов трудоустройства, адаптации, материального благоустройства и др. Письма позволяют дополнить биографические канвы жизни Ф.Г. Александрова и А.В. Флоровского и почерпнуть новые сведения для них, которые ранее не упоминались в биографических статьях двух корреспондентов. Множество подробностей их педагогической, научной и частной жизни могут послужить прекрасным дополнением к просопографическим портретам двух ученых.

Ключевые слова: Ф.Г. Александров, А.В. Флоровский, русское зарубежье, София, Болгария, эпистолярий, переписка, историография. 